\title{
Technology addiction of adolescents in the COVID-19 era: Mediating effect of attitude on awareness and behavior
}

\author{
Nihan Potas ${ }^{1}$ (D) - Şuay Nilhan Açıkalın ${ }^{2}$ (D) - Şefika Şule Erçetin ${ }^{3}$ (D) Nilüfer Koçtürk $^{3}$ (D) $\cdot$ Nilay Neyişci $^{3}$ (D) \\ Mehmet Sabir Çevik ${ }^{3}$ (D) Deniz Görgülü ${ }^{3}$ (i)
}

Accepted: 3 February 2021 / Published online: 13 February 2021

(C) The Author(s), under exclusive licence to Springer Science+Business Media, LLC part of Springer Nature 2021

\begin{abstract}
Adolescents have been called the "digital natives of the technology age", but determining adolescents' awareness, attitudes and behavior with respect to technology addiction (TA) is important for developing balanced and effective approaches to support their physical and psychological well-being after the COVID-19 pandemic. For this reason, the present study investigates the impact of attitudes on TA behavior in 382 adolescents by gender and extent of technology use. Three scales were used to determine adolescents' TA awareness, attitude, and behavior. The results of the dual-moderated mediation model show that gender and duration of technology use (h) moderated the full mediation of attitude on awareness and behavior in TA $(F=39.29$, $d f=9 ; 372, p<.01)$. The indirect effect in males with $16.04 \mathrm{~h}$ per day of technology use is stronger $(.24)$ than the indirect effect in males with $4.90 \mathrm{~h}$ per day of technology use (.13). In addition, the simple slope plot shows that when attitude scores increase, addictive behavior rises in females (simple slope $=.74, t=8.79, p<.01$ ). On the other hand, with $16.04 \mathrm{~h}$ per day of technology use, when attitude scores decrease, addictive behavior rises in females (simple slope $=.69, t=7.59, p<.01$ ). Furthermore, when the attitude scores increase, addictive behavior rises in males (simple slope $=.85, t=13.26, p<.01$ ). As a result, the psychoeducational intervention programs to be implemented for TA should not only focus on awareness, but should also encompass behavioral, cognitive and lifestyle changes.
\end{abstract}

Keywords COVID-19 $\cdot$ Adolescent $\cdot$ Technology addiction $\cdot$ Awareness $\cdot$ Attitude $\cdot$ Dual moderator mediation model

Due to developments in information and communication technology, the frequent use of technological devices such as smartphones, computers and tablets is widespread among adolescents. According to a study by the Turkish Statistical Institute (TÜIK, 2013), late adolescents are the second highest users of technology in Turkey, with men (94.8\%) using technology more than women $(86.6 \%)$ in this age group (TÜiK, 2019a). In addition to improvements in information and communications technology, a currently emerging global

Nihan Potas

nihan_potas@hotmail.com

Șuay Nilhan Açikalın

suaynilhan@gmail.com

Şefika Şule Erçetin

sefikasule@gmail.com

Nilüfer Koçtürk

niluferkocturk@hacettepe.edu.tr

Nilay Neyișci

nilbasar@hacettepe.edu.tr challenge is the novel coronavirus disease of 2019 (COVID19; El Zowalaty \& Järhult, 2020; Wang, Horby, Hayden, \& Gao, 2020). Stay-at-home orders, curfews, self-isolation, social distancing, social isolation, and quarantining have led people to change their ways of life and affected their relationships (Okunlola, Lamptey, Senkyire, Dorcas, \& Dooshima, 2020). As many daily activities, from work and education to healthcare and beyond, move from public spaces into homes, the use of technology and the internet has increased

Mehmet Sabir Çevik

sahici1980@gmail.com

Deniz Görgülü

denizgorgulu87@gmail.com

1 Department of Health Care Management, Ankara Hacı Bayram Veli University, Ankara, Turkey

2 Department of International Relations, Ankara Hacı Bayram Veli University, Ankara, Turkey

3 Department of Education Science, Hacettepe University, Ankara, Turkey 
dramatically (Ahorsu et al., 2020; King, Delfabbro, Billieux, $\&$ Potenza, 2020). While some people regard the use of technology as a means of escaping depression, anxiety, or helplessness (Hinić, Mihajlović, Špirić, Dukić-Dejanović, \& Jovanović, 2008), the increased time spent online can also result in an increase in social interaction and integration (Magsamen-Conrad, Billotte-Verhoff, \& Greene, 2014). These factors too may increase the need to use technology and ultimately escalate it to the level of addiction. The excessive use of technological tools during the COVID-19 outbreak has been found to multiply the probability of it being a risk factor for addiction by two or more times, especially as the duration of use increases (Aliyev, 2020; Király et al., 2020; Winther \& Byrne, 2020). The public should therefore pay serious attention to the possibility of TA during the pandemic.

Addiction, refers to physiological dependence between a person and some stimulus, such as a substance (Davis, 2001). TA is defined as "a user's psychological state of maladaptive dependency on IT use that is manifested through the obsessive-compulsive pattern of IT-seeking and IT-use behaviors that take place at the expense of other important activities" (Xu, Turel, \& Yuan, 2012, p. 321). However, there is no clear consensus in the literature about the scope and definition of the concept of TA. Many terms such as internet addiction disorder, compulsive internet use, problematic or pathological internet use, computer addiction and pathological use of video games have also been used to describe this phenomenon (Hekim et al., 2019; Turel, Serenko, \& Giles, 2011). Because there is insufficient evidence to establish the diagnostic criteria needed to identify it as a separate mental disorder, TA is regarded as a behavioral disorder in DSM-5 (American Psychiatric Association, 2013; Hekim et al., 2019; Serenko \& Turel, 2020).

Some researchers have described TA as the epidemic of the twenty-first century. It has become common in many societies (Serenko \& Turel, 2020). It is seen as a behavioral problem that negatively affects human life as a result of excessive use and can cause problematic outcomes in the life of the individual due to loss of control (Kuss \& Griffiths, 2015; Kuss, Griffiths, Karila, \& Billieux, 2014; Young \& Nabuco de Abreu, 2011). The literature emphasizes that adolescents with TA addiction face several physical and mental health problems, including visual impairment, spinal disorders, finger numbness, arm pain, bulimia, obesity, insomnia, anger problems, aggression, antisocial behavior, suicide attempts, anxiety disorder, and depression, among many others (Cheung \& Wong, 2011; Cho, Sung, Shin, Lim, \& Shin, 2013; Eliacik et al., 2016; Gerçel \& Çağlar, 2016; Hekim et al., 2019; Karapetsas \& Fotis, 2020; Tao, 2013). TA is also significantly related with poor academic outcomes (Adiele \& Olatokun, 2014). In brief, TA is typically associated with negative outcomes for adolescents.

Parents, peers, and teachers are important role models in the process of the development of positive forms of behavior in adolescents, both in general and during the pandemic (Mason \& Windle, 2002; Xie, Chen, Zhu, \& He, 2019). Parents and teachers are also the first and second most effective elements, respectively, in protecting adolescents from TA. In other words, in accordance with Bronfenbrenner's ecological system theory (Shelton, 2018), the family and the social environment are important factors that influence adolescents' technology use. For example, previous findings indicate that phubbing (ignoring other people by busying oneself with a digital device) on the part of parents is a TA risk factor for adolescent's TA (Xie et al., 2019). In addition, previous studies have emphasized the effects of the awareness of parents and teachers about TA on awareness and technology use among adolescents (Ebbeck, Yim, Chan, \& Goh, 2016; Jabbar, Al-Shboul, Tannous, Banat, \& Aldreabi, 2019; Karadağ \& Kılıç, 2019; Ybarra \& Mitchell, 2004). The approaches of parents and teachers to discipline and their styles of communication affect adolescents' awareness of many issues in life (Düzgün, 2003; Moazedian, Taqavi, Hosseinialmadani, Mohammadyfar, \& Sabetimani, 2014). However, it may not be possible for parents and teachers to be consistent in their approaches during the COVID-19 outbreak due to their own individual problems, which may include health, economic and psychological problems. The experience of previous pandemics shows that the economic, social and psychological stresses combined with cramped homes, movement restrictions and stay-at-home orders can alter the family climate (UN Women, 2020; World Health Organization, 2020).

Previous studies indicate that adolescents' awareness or education with respect to TA addiction can be an effective factor in preventing it or reducing the amount of harm it causes (Kuss, Van Rooij, Shorter, Griffiths, \& Van De Mheen, 2013; Xu et al., 2012). In addition, regarding the relationship between attitude and behavior, individuals with more positive attitudes can be said to engage in desirable forms of behavior more than individuals who have a negative attitude (Kim \& Choi, 2005; Selai, 1998; Streufert, 1987). In the literature, an attitude is defined as a relatively stable, general and enduring evaluation of a group, person, object, issue, or concept on a dimension ranging from negative to positive. Awareness is defined as the "perception or knowledge of something" (VandenBos, 2015). Whereas awareness is a cognitive process based on knowledge (Sweldens, Corneille, \& Yzerbyt, 2014), attitudes provide summary evaluations of objects and are often assumed to be derived from specific emotions, beliefs, and past behavior associated with those objects (VandenBos, 2015). As the definitions show, awareness of TA alone may not be sufficient to measure actual behavior. The literature states that attitude affects behavioral intent and shapes awareness (Ajzen, 2005; Kollmuss \& Agyeman, 2002). According to Kağıtçıbașı (2010), when we need to act, we focus on our attitude to the situation and let it lead 
us, and the mindful cognitive processes we go through cause our behavior to be affected by our attitudes. On the other hand, the relationship between attitude and behavior is one of the issues discussed in the literature (Fishbein \& Ajzen, 2010). It is known that various sociocognitive theories have been developed in the literature to explain the relationship between attitude and behavior. According to the planned behavior theory (Montaño \& Kasprzyk, 2015), which is one of these theories, the relationship between attitude and behavior is explained within the framework of a mediating variable model. According to Fishbein and Ajzen (2010), at the basis of individuals' behaviors, there are beliefs that are fed from different sources such as individuals' personalities, internet. These beliefs affect whether the individual will behave or not regardless of the source they are fed. According to the reasoned action approach, the most obvious premise of an individual to perform a behavior is the intention of the individual to perform this behavior (Ajzen, 2012; Montaño \& Kasprzyk, 2015). It is attitudes and subjective norms that determine intention. In the context of these theories, attitude can therefore be expected to mediate the relationship between awareness and technology addiction. In this sense, the mediating effect of attitude emerges as an important point, and this hidden link can reveal itself intensely during the COVID-19 outbreak.

Prolonged use of technology is one indicator of TA. Widyanto, Griffiths, and Brunsden (2011) found that the more time a user spends on the Internet, the higher likelihood of TA addiction. Indeed, in a study examining the relationship between social norms and social site usage, it is found that time spent on the social platform had a significant effect on the relationship between social norm and social site continuance (Osatuyi \& Turel, 2019). The moderating influence of the amount of time spent on the social site suggests that social influence is more prominent when one spends more time on the site. This study shows that the more time a user spends on those sites, the higher the influence of social norm on their continuous use behavior. In other words, the duration of internet use can affect the individual's attitude and cause behavioral change. However, in the literature, there is no study conducted with adolescents and investigating the moderation effect of the prolonged use of technology.

Gender is undeniably a variable that affects awareness, attitudes, and behavior in TA. There are various findings in the literature that associate gender with TA (Dufour et al., 2016; Ha \& Hwang, 2014; Su, Han, Jin, Yan, \& Potenza, 2019). While some studies have shown that males are more prone to TA (Bandawar, Narasimha, \& Chand, 2018; Vollmer, Randler, Horzum, \& Ayas, 2014), others have shown that the use of technological tools is higher among female adolescents than their male counterparts (Gerçel \& Cağlar, 2016). One study found that the prevalence rate was $3.3 \%$, in a male to female ratio of approximately $3: 1$ (Adiele \& Olatokun, 2014). A number of studies show that women generally display a positive but lower (weaker) attitude towards technology use than their male counterparts (Ardies, De Maeyer, Gijbels, \& van Keulen, 2015; Sáinz \& LópezSáez, 2010; Yau \& Cheng, 2012). Gender differences are observed to occur in terms of attitudes towards technology use, prior to observable behavioral levels (Cai, Fan, \& Du, 2017; Shashaani, 1994). Cai et al. (2017) suggested that this gender difference in attitudes may be responsible for many of the forms of behavior that are associated with the widespread notions that technology is a male-dominated field and that men are more competent users of technology, as well as other social and cultural norms. Some researchers have suggested that gender differences may arise from parental attitudes (Vollmer et al., 2014). On the other hand, all these gender differences may not apply in the same way during the COVID-19 pandemic under conditions of social isolation, curfews and social withdrawal. Moreover, the differences among the findings of previous studies suggest that there may be other factors which affect or mediate the relationship between gender and the use of technological tools or TA (Ardies et al., 2015; Cai et al., 2017; Sáinz \& López-Sáez, 2010; Xu et al., 2012). For instance, the differentiation in the characteristics of adolescents, such as a need for relationships and a need for escapism, is a factor that affects TA status (Xu et al., 2012). However, assuming that all adolescents have similar social needs (e.g., a need for relationships and a need for escapism), there may be no difference between the genders for TA during the COVID-19 pandemic. Fresh studies are needed in order to reach a firm conclusion.

\section{Study Aim and Hypothesis Development}

Adolescents have been called the "digital natives of the technology age", but their awareness, attitudes and behavior related to TA should nevertheless be shaped and monitored (Prensky, 2001). This is especially true during the COVID19 pandemic, as TA could lead to difficulties in re-adapting to "normal" life after the crisis, which could negatively affect the quality of their lives. Habits are hard to break, and adolescence is a critical stage in terms of addiction development. Determining adolescents' awareness, attitudes and behavior with respect to TA is important for developing balanced and effective approaches to support their physical and psychological well-being after the pandemic. In addition, although studies about TA are common in many developed countries, it has just started to become widespread the last 10 years in Turkey (Ayas \& Horzum, 2013). For this reason, the present study intends to determine the level of awareness, attitudes and behavior of adolescents related to TA during the COVID-19 outbreak. Drawing on social learning theory (Bandura, 1969) and Bronfenbrenner's ecological system theory (Shelton, 2018), the study aims to use the mediation model 
to test whether the indirect effect of attitude or the direct effect of awareness has a stronger impact on behavior. The study then examines whether gender and the extent of technology use influence the strength of these impacts using a dualmoderated mediation model. Based on the theory and previous findings, the following hypotheses were formulated (Dinçman \& Akbaşl1, 2020) and the model was presented as in Fig. 1:

$\boldsymbol{H}_{1}$ : As awareness of TA increases, adolescents' TA behavior decreases during the COVID-19 outbreak.

$\boldsymbol{H}_{2}$ : Adolescents' attitudes to TA mediate the direct effect of awareness on TA behavior during the COVID-19 outbreak.

$\boldsymbol{H}_{2 \boldsymbol{a}}$ : As awareness of TA increases, adolescents' attitudes scores to TA increase.

$\boldsymbol{H}_{2 \boldsymbol{b}}$ : As attitudes to TA increase, adolescents' TA behavior increases.

$\boldsymbol{H}_{3}$ : Gender moderates the indirect effect at the second stage of mediation (between attitude and behavior), rather than at the first stage of mediation (between awareness and behavior) during the COVID-19 outbreak.

$\boldsymbol{H}_{4}$ : Higher duration of technology use (hours) and gender moderate the indirect effect at the second stage of mediation (between attitude and behavior), rather than at the first stage of mediation (between awareness and behavior) during the COVID-19 outbreak.

\section{Methodology}

\section{Participants}

The study employed a cross-sectional approach in which quantitative data were collected through the self-reported survey method. There were 257 (67.3\%) female and 125 (32.7\%) male adolescent participants. The participants were aged between 10 and 19. The mean age of the participants was 14.92 years $(S D=3.18)$. Of the adolescents, $64.92 \%(n=$ $248)$ are studying in secondary school and $35.08 \%(n=134)$ in high school. The marital status of the adolescents' parents was given as: $16.75 \%(n=64)$ single and $83.25 \%(n=318)$ married. The level of education of the adolescents' mothers was as follows: $3.66 \%(n=14)$ primary school, $11.78 \%(n=$ $45)$ secondary school, $56.81 \%(n=217)$ high school, $24.61 \%$ $(n=94)$ associate or undergraduate degree, and $3.14 \%(n=$ 12) master's degree or PhD. The level of education of the adolescents' fathers was as follows: $1.83 \%(n=7)$ primary school, $4.71 \%(n=18)$ secondary school, $35.34 \%(n=135)$ high school, $46.86 \%(n=179)$ associate or undergraduate degree, and $11.26 \%(n=43)$ master's degree or PhD. The proportion of the adolescents who came from families with an average monthly income of TRY0-3000 (USD 0-389) was $21.20 \%(n=81)$. This proportion was $44.25 \%(n=169)$ for TRY3001-6000 (USD390-780) and 34.55\% $(n=132)$ for TRY6001 (USD781) or above.

The study used an adjective checklist for adolescents to describe themselves and their parents (Gough \& Heilbrun, 1965). Adolescents mostly described their parents in the first order as good parents $(n=211,55.2 \%)$, in the second order as concerned parents $(n=138,36.1 \%)$, and in the third order as authoritarian $(n=80,20.9 \%)$ and boring $(n=80,20.9 \%)$ parents. Adolescents mostly described themselves in the first order as a good person $(n=260,68.1 \%)$, in the second order as a funny person $(n=195$, $51.0 \%)$ and in the third order as a calm person $(n=179,46.9 \%)$.

The TA scores of the adolescents were first grouped by the marital status of their parents. Adolescents whose parents were single had a low level of awareness $(1.99 \pm .36)$, positive attitudes (3.48 \pm .39 ), and a high level of addictive behavior (3.57 $\pm .41)$. Adolescents whose parents were married had a moderate level of awareness $(2.00 \pm .35)$, positive attitudes (3.52 \pm .36 ), and a high level of addictive behavior (3.59 \pm .39$)$.

The TA scores of the adolescents were then grouped by their perceptions of their parents. Adolescents who described

Fig. 1 Hypothesized model

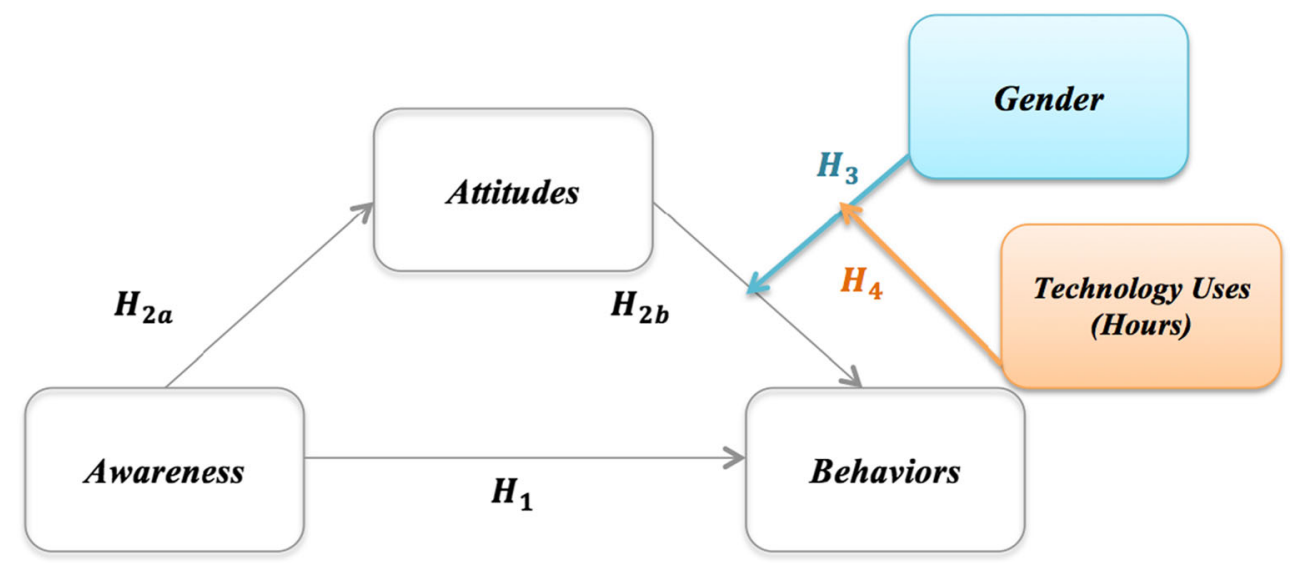


their parents as good parents had a low level of awareness $(1.98 \pm .34)$, positive attitudes (3.54 \pm .37$)$, and a high level of addictive behavior (3.62 \pm .39 ). Adolescents who described their parents as concerned parents had a low level of awareness $(1.99 \pm .37)$, positive attitudes $(3.50 \pm .38)$, and a high level of addictive behavior ( $3.58 \pm .38$ ). Adolescents who described their parents as authoritarian parents had a low level of awareness (1.98 \pm .35$)$, positive attitudes (3.50 \pm .39$)$, and a high level of addictive behavior ( $3.58 \pm .38)$. Adolescents who described their parents as boring parents had a moderate level of awareness $(2.05 \pm .35)$, positive attitudes $(3.50 \pm .37)$, and a high level of addictive behavior ( $3.58 \pm .34)$.

The TA scores of the adolescents were also grouped by their self-evaluations. Adolescents who described themselves as a good person had a moderate level of awareness (2.00 $\pm .35)$, positive attitudes ( $3.53 \pm .36)$, and a high level of addictive behavior $(3.57 \pm .37)$. Adolescents who described themselves as a funny person had a moderate level of awareness $(2.03 \pm .35)$, positive attitudes ( $3.50 \pm .37)$, and a high level of addictive behavior ( $3.58 \pm .39$ ). Adolescents who described themselves as a calm person had a moderate level of awareness $(2.01 \pm .35)$, positive attitudes $(3.49 \pm .38)$, and a high level of addictive behavior ( $3.53 \pm .40)$.

\section{Measurement Tools}

\section{The Personal Information Form}

The form was developed by the researchers and was used to obtain information about the gender and age of the adolescents and the amount of time they spend using technology. The form was also used to ask adolescents to describe themselves and their parents by ticking off the options they considered to be appropriate for themselves and their parents from a given list of personal attributes (e.g., concerned parents, authoritarian parents). Via the form, the participants were also asked for sociodemographic information about their parents, and for information on their parents' marital status. Levels of education and approximate levels of income.

\section{Awareness, Attitude, and Behavior in the TA Scale}

Awareness in TA, Attitude in TA and Behavior in TA Scales were administered. The scales were designed according to the use of technology devices with internet connections such as computers, mobile phones and tablets. The 3D Scale for Awareness, Attitude and Stigma of Addiction was developed for a national project (funded by the Republic of Turkey's Ministry of Youth and Sports Youth Projects Support Program II of 2014; Potas et al., 2016). In this project; the 'psychometric measurement' patterns of addiction (e.g., awareness, attitudinal, stigmatization and behavioral) were used. The scales were taken from the earlier project and adapted for technology addiction (Potas et al., 2016; Potas, Erçetin, Nilhan Açıkalın, Güngör, \& Soydaş Akyol, 2018). Detailed information about the scales is given in Appendix 1.

The awareness scale consists of 19 items, rated on a 4-point scale with responses ranging from 1 (Strongly disagree) to 4 (Strongly agree). The scores are classified as follows: $1-1.99=$ none or low; $2-2.99=$ moderate; 3-3.99 = high. Sample items from the awareness scale are "Technology addiction can lead to many personal, family and social problems" and "Technology addicts cannot control themselves in using technological tools". The attitude scale consists of 8 items, and items are rated positive or negative using a 4-point scale: (1) Definitely negative, (2) Negative, (3) Positive, and (4) Definitely positive. The scores are classified as follows: $1-1.99=$ negative; $2-2.99=$ neutral; 3-3.99= positive (Hair, Gabriel, da Silva, \& Braga Junior, 2019; Mcleod, 2009). Sample items from the attitude scale are "Technology addiction prevents success" and "Technology addiction can be reduced under the supervision of our parents". The behavior scale consists of 10 items measuring the frequency of certain kinds of behavior using a 4point scale with responses ranging from 1 (Never) to 4 (Always). These scores are classified as follows: 1-1.99= low; $2-2.99=$ moderate; $3-3.99=$ high. Sample items from the behavior scale are "I limit my use of technological tools" and "I inform my friends about technology addiction". In line with the literature (Louangrath, 2018), higher scores on the TA scale indicate a more severe level of TA.

In the present study, the Cronbach's $\alpha$ reliability of the scales was .78 for the awareness scale, .83 for the attitude scale, and .90 for the behavior scale. For concurrent validation of their TA behavior, the participants were also asked to complete the smartphone addiction scale-short version (SAS-SF10 item), Young's Internet addiction test-short form (YIA-SF12 item), and Chen's internet addiction scale (CIAS-26 item) (Chen, Weng, Su, Wu, \& Yang, 2003; Kwon et al., 2013; Young, 1998; Young \& Nabuco de Abreu, 2011). The following correlation coefficients were considered: small validity $\rho$ $<.25$; moderate validity $\rho=.25-.50$; good validity $\rho=.50-.75$; and excellent validity: $\rho>.75$ (Portney \& Watkins, 2007). The correlation coefficients indicated good validity for TA behavior and SAS-SF $(\rho=.64, p<.01)$, good validity for TA behavior and YIA-SF $(\rho=.57, p<.01)$ and good validity for TA behavior and CIAS $(\rho=.61, \mathrm{p}<.01)$. Evaluating all the validity and reliability results together, it was concluded that the awareness, attitude, and behavior items in the TA scales are a suitable measurement tool that can be used psychometrically (Table 1, Appendix 1: Figs. 4, 5 and 6).

\section{Data Collection}

The study was approved by the Ethics Committee (AHBV2020/133). After receiving ethical approval, data were collected from adolescents in Turkey from April 7 to May 7, 2020. 
Table 1 Results of Exploratory Factor Analysis (EFA) and Confirmatory Factor Analysis (CFA)

\begin{tabular}{lccc}
\hline & Awareness in TA & Attitude in TA & Behavior in TA \\
\hline Items & 19 & 8 & 10 \\
Sub-dimensions & 6 & - & - \\
KMO & .78 & .83 & .90 \\
Total Variance Explained & $55.72 \%$ & $45.37 \%$ & $45.80 \%$ \\
Factor Eigenvalues & $1.09-4.27$ & 3.63 & 4.58 \\
Factor Loading & $.42-.89$ & $.55-.69$ & $.45-.77$ \\
Barlett test $\chi^{2}$ & 1821.624 & 895.826 & 1313.025 \\
Cronbach's Alpha & .78 & .82 & .86 \\
Item-Total correlation & $.40-.57$ & $.50-.62$ & $.42-.70$ \\
$N F I$ & .90 & .95 & .96 \\
$N N F I$ & .96 & .95 & .96 \\
$C F I$ & .97 & .97 & .97 \\
$I F I$ & .97 & .97 & .97 \\
$R M R$ & .04 & .02 & .02 \\
SRMR & .06 & .04 & .05 \\
$R M S E A$ & .039 & .078 & .075 \\
$\chi^{2} / S d$ & 1.43 & 2.54 & 2.57 \\
\hline
\end{tabular}

$T A$ Technology addiction, $K M O$ Kaiser-Meyer-Olkin
Due to the COVID-19 outbreak, Turkey began implementing distance education on March 23, 2020. The data collection process coincided with the curfew period for adolescents in Turkey.

Stratified sampling, a probability sampling method, was used to determine the sample size based on the adolescent population reported by the Turkish Statistical Institute (TÜİK) for 2019. According to TÜİK, there were $6,406,170$ preadolescents aged 10 to 14 in Turkey in 2019 and 6,331,594 older adolescents aged 15 to 19 (TÜİK, 2019b). The strata for the stratified sampling were determined according to the age of the participants. With a $5 \%$ margin of error, the total sample was calculated to be 385 . The criteria for inclusion in the study were that the participants should have internet access and that both the adolescents and their parents should consent to their participation. Accordingly, the exclusion criteria were lack of internet access and absence of consent from the adolescent or parent. Cases where participants gave identical answers or where a lot of answers were missing were also treated as exclusion criteria.

Information about the study was initially communicated to working school teachers. The teachers announced the study during their online meetings with students and their parents and provided the researcher's contact information to those willing to participate in the study. Before sending the Google online survey to the participants who contacted the researchers by e-mail, we informed the adolescents and their parents about the scope of this study, both verbally and in online written form, and asked them to consent to participate in the study. Information on the parents' educational backgrounds and parental consent was obtained from the parents. However, in accordance with ethical principles, consent was also obtained from the adolescents. After receiving consent, we directed the participants to the Google survey site.

A total of 395 participants requested to take the online survey. Of the participants, 13 were excluded from the study because all their answers were identical. A power analysis was performed to check whether the remaining number of 382 participants was sufficient for the study, Correlation results were used for the power calculation. According to Fig. 2, a sample size of 260 achieves $98.20 \%$ power with a significance level of .01 to detect an effect size of .27 .

\section{Statistical Analysis}

The validity and reliability of the scales were determined by using LISREL 8.80 software. The dual-moderated mediation analysis was performed using R 3.5.3, SPSS 23.0 according to the hypothesis model (Fig. 1). The paths were analyzed with multiple regression. All the assumptions for the multiple regressions were checked. The point-biserial and Pearson's coefficients of correlation were used to evaluate the relationship between each variable. To test whether the sample used in the study was sufficient or not, the results of the correlation analysis were studied using power analysis ( $\mathrm{G}^{*}$ Power 3.1.9.4 software). The $P$-values were two-sided, and differences were considered significant at .05 .

\section{Results}

The mean daily duration of the participants' use of technology was $10.46 \mathrm{~h}$ per day. The correlations between gender, age, 
Fig. 2 Total sample size according to the power $(1-\beta)$ t tests - Correlation: Point biserial mode

Tail(s) $=$ Two, Effect size $|\rho|=0,265895$

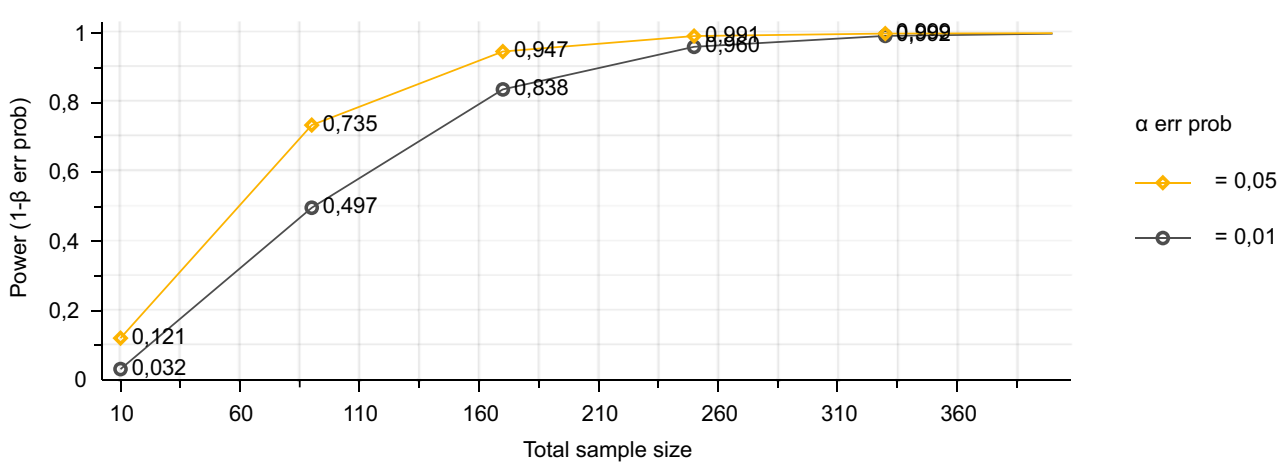

duration of technology use (hours), attitude, awareness, and behavior are presented in Table 2 . There were significantly positive and high correlations $(p<.01)$ between behaviour and attitude, whereas awareness-attitude and behaviorawareness had significant correlations $(p<.01)$ that were negative and low $(-.27<\rho<-.25)$.

The influence of awareness of TA (X) on behavior in TA (Y) $[\mathrm{X} \rightarrow \mathrm{Y}]$, of awareness of TA $(\mathrm{X})$ on attitude to TA $(\mathrm{M})$ $[\mathrm{X} \rightarrow \mathrm{M}]$, and of awareness of TA $(\mathrm{X})$ and attitude to TA $(\mathrm{M})$ on behavior in $\mathrm{TA}(\mathrm{Y})[\mathrm{X}+\mathrm{M} \rightarrow \mathrm{Y}]$ were tested using a simple meditation model. In the first case, Model 1 was statistically significant $(F=13.14, d f=2 ; 379, p<.01)$. In Model 1 , as awareness $(\mathrm{X})$ of TA increases, adolescents' behavior $(\mathrm{Y})$ in TA decreases during the COVID-19 outbreak $(\beta=-.27$, $p<.01)$. This supports $H_{1} \boldsymbol{H}_{1}$. In the second case, Model 1 was statistically significant $(F=15.94, d f=2 ; 379, p<.01)$. In Model 1, as awareness (X) of TA increases, the scores for adolescents' attitudes scores (M) to TA decrease $(\beta=-.29$, $p<.01)$. This supports $H_{2 a}$. In the third case, concerning the relationship between attitude and behaviour, the model was statistically significant too $(F=163.43, d f=9 ; 379, p<.01)$ as attitude to TA increases, adolescents' behavior in TA increases as well $(\beta=.71, p<.01)$, thereby supporting $H_{2 b}$. Thus, attitude (M) in TA mediates the direct effect of awareness $(\mathrm{X})$ on behavior $(\mathrm{Y})$ in $\mathrm{TA}$ in adolescents during the
COVID-19 outbreak. The coefficient of attitude (indirect effect) was statistically significant, while the coefficient of awareness (direct effect) was not. Furthermore, $\mathrm{X}+\mathrm{M} \rightarrow \mathrm{Y}$ in Model 2 was statistically significant $(F=123.94, d f=$ $3 ; 376, p<.01)$ too. Consequently, $H_{2}$ is supported. Model 2 shows that when the three conditions are met, full mediation is supported.

Secondly, the influence of awareness of TA (X), attitude to TA (M), gender (W), and the interaction term between attitude and gender $(\mathrm{M} \times \mathrm{W})$ on behavior in TA $(\mathrm{Y})[\mathrm{X}+$ $\mathrm{M}+\mathrm{W}+\mathrm{M} \times \mathrm{W} \rightarrow \mathrm{Y}$ ] was tested using a moderated mediation model. Here, Model 3 and the coefficient of attitude were statistically significant $(F=74.05, d f=5 ; 376$, $p<.01)$, while the interaction term between gender and attitude was not $(\beta=.03, p>.05)$. The indirect effect of attitude $(\mathrm{M})$ to $\mathrm{TA}$ on the adolescents' behavior $(\mathrm{Y})$ in TA was found not be moderated by gender (W), such that the indirect effect would be equal among females and males. Therefore, $H_{3}$ was not supported.

Next, the influence of awareness in TA (X), attitude to TA $(\mathrm{M})$, gender $(\mathrm{W})$, duration of technology use $(\mathrm{Z})$, an interaction term between attitude and duration of technology use $(\mathrm{M} \times \mathrm{Z})$, an interaction term between attitude and gender $(\mathrm{M} \times \mathrm{W})$ and an interaction term between attitude and gender and duration of technology use $(\mathrm{M} \times \mathrm{W} \times \mathrm{Z})$ on behavior in

Table 2 Mean, standard deviation, point-biserial correlations and pearson correlations among variables

\begin{tabular}{|c|c|c|c|c|c|c|c|c|}
\hline & $\mathbf{x}$ & SD & (1) & (2) & (3) & (4) & $(5)$ & (6) \\
\hline 1. Gender & 1.33 & .47 & 1 & & & & & \\
\hline 2. Age & 14.92 & 3.18 & -.01 & 1 & & & & \\
\hline 3. Technology use per day (hours) & 10.47 & 5.57 & -.05 & $.10^{*}$ & 1 & & & \\
\hline 4. Attitude & 3.53 & .38 & .03 & .05 & .02 & 1 & & \\
\hline 5. Awareness & 2.07 & .37 & -.05 & .05 & $.11^{*}$ & $-.27^{* *}$ & 1 & \\
\hline 6. Behaviour & 3.57 & .39 & .04 & .02 & $.50^{* *}$ & $.70^{* *}$ & $-.25^{* *}$ & 1 \\
\hline
\end{tabular}

$n=382 ; \mathrm{SD}=$ Standard deviation

$* p<.05, * * p<.01$ 
Table 3 Results of competing models of simple mediation, moderated mediation and dual moderated mediation

\begin{tabular}{|c|c|c|c|c|c|}
\hline & \multicolumn{5}{|c|}{ Dependent variable: } \\
\hline & \multirow{2}{*}{$\begin{array}{l}\text { M: Attitude } \\
\text { Model } 1\end{array}$} & \multicolumn{4}{|l|}{ Y: Behaviour } \\
\hline & & Model 1 & Model 2 & Model 3 & Model 4 \\
\hline \multicolumn{6}{|l|}{ Step 1: Control Variables } \\
\hline Age & $\begin{array}{l}.01 \\
(.01)\end{array}$ & $\begin{array}{l}.01 \\
(.01)\end{array}$ & $\begin{array}{l}-.00 \\
(.19)\end{array}$ & $\begin{array}{l}-.00 \\
(.00)\end{array}$ & $\begin{array}{l}-.00 \\
(.00)\end{array}$ \\
\hline \multicolumn{6}{|l|}{ Step 2: Mediator } \\
\hline M: Attitude & & & $\begin{array}{l}.69 * * \\
(.04)\end{array}$ & $\begin{array}{l}.68 * * \\
(.05)\end{array}$ & $\begin{array}{l}.33^{* *} \\
(.11)\end{array}$ \\
\hline \multicolumn{6}{|l|}{ Step 3: Independent variable } \\
\hline $\mathrm{X}$ : Awareness & $\begin{array}{l}-.29 * * \\
(.05)\end{array}$ & $\begin{array}{l}-.27 * * \\
(.05)\end{array}$ & $\begin{array}{l}-.07 \\
(.04)\end{array}$ & $\begin{array}{l}-.07 \\
(.04)\end{array}$ & $\begin{array}{l}-.06 \\
(.04)\end{array}$ \\
\hline \multicolumn{6}{|l|}{ Step 4: Moderator } \\
\hline W: Gender & & & & $\begin{array}{l}-.10 \\
(.28)\end{array}$ & $\begin{array}{l}-1.53^{* *} \\
(.58)\end{array}$ \\
\hline Z: Technology use (Hours) & & & & & $\begin{array}{l}-.12 * * \\
(.03)\end{array}$ \\
\hline \multicolumn{6}{|l|}{ Step 5: Moderating Effect } \\
\hline $\mathrm{M} \times \mathrm{W}$ & & & & $\begin{array}{l}.03 \\
(.08)\end{array}$ & $\begin{array}{l}.43 * * \\
(.16)\end{array}$ \\
\hline $\mathrm{M} \times \mathrm{Z}$ & & & & & $\begin{array}{l}.03 * * \\
(.01)\end{array}$ \\
\hline $\mathrm{W} \times \mathrm{Z}$ & & & & & $\begin{array}{l}.13^{* *} \\
(.05)\end{array}$ \\
\hline $\mathrm{M} \times \mathrm{W} \times \mathrm{Z}$ & & & & & $\begin{array}{l}-.04 * * \\
(.01)\end{array}$ \\
\hline Constant & $\begin{array}{l}2.55^{* *} \\
(.19)\end{array}$ & $\begin{array}{l}2.68 * * \\
(.19)\end{array}$ & $\begin{array}{l}.91 * * \\
(.19)\end{array}$ & $\begin{array}{l}.94 * * \\
(.20)\end{array}$ & $\begin{array}{l}2.24 * * \\
(.40)\end{array}$ \\
\hline $\mathbf{R}^{2}$ & .08 & .06 & .49 & .50 & .52 \\
\hline F Statistic & $\begin{array}{l}15.94 * * \\
(d f=2 ; 379)\end{array}$ & $\begin{array}{l}13.14 * * \\
(d f=2 ; 379)\end{array}$ & $\begin{array}{l}123.94 * * \\
(d f=3 ; 378)\end{array}$ & $\begin{array}{l}74.05 * * \\
(d f=5 ; 376)\end{array}$ & $\begin{array}{l}43.92 * * \\
(d f=9 ; 372)\end{array}$ \\
\hline
\end{tabular}

$p^{*}<.05, p^{* *}<.01$

TA (Y) $[\mathrm{X}+\mathrm{M}+\mathrm{Z}+\mathrm{M} \times \mathrm{Z}+\mathrm{M} \times \mathrm{W}+\mathrm{W} \times \mathrm{Z}+\mathrm{M} \times \mathrm{W} \times$ $\mathrm{Z} \rightarrow \mathrm{Y}$ ] was tested using a dual-moderated mediation model. While the coefficient of attitude, gender, and duration of technology use were statistically significant, the coefficient of awareness was not. Moreover, Model 4 was statistically significant $(F=43.92, d f=9 ; 372, p<.01)$, as well as all of the interaction terms $\left(\beta_{\mathrm{M} \times \mathrm{W}}=.43, p<.01 ; \beta_{\mathrm{M} \times \mathrm{Z}}=.03, p<.01\right.$;

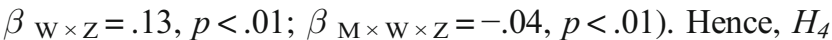
was supported as the indirect effect of attitude (M) to TA on the adolescents' behavior $(\mathrm{Y})$ in TA would not be moderated by gender $(\mathrm{W})$ and duration of technology use (Z) (Table 3).

In dual-moderated mediation (Model 4), bootstrapping results showed that the confidence interval of bootstrapping crossed zero for both males and females with the duration of technology use. Using the formula $\mu \pm \sigma$, the result [4.9016.04] was obtained from the estimation of $\mu$ and $\sigma$.
Therefore, the range always contains $68 \%$ data (Coolican, 2017). The indirect effect for males with $16.04 \mathrm{~h}$ per day of technology use is stronger (.24) than the indirect effect for males with $4.90 \mathrm{~h}$ per day of technology use (.13). Model 4 includes more than one mediator, and comparisons are made within the mediator (Hayes, 2013, 2015) (Table 4).

The simple slope plot shows that, with $4.90 \mathrm{~h}$ per day of technology use, when attitude scores decrease, addictive behavior rises in males (simple slope $=.49, t=6.99, p<.01$ ). However, when attitude scores increase, addictive behavior rises in females (simple slope $=.74, t=8.79, p<.01$ ). On the other hand, with $16.04 \mathrm{~h}$ per day of technology use, when attitude scores decrease, addictive behavior rises in females (simple slope $=.69, t=7.59, p<.01$ ). Furthermore, when the attitude scores increase, addictive behavior rises in males ( simple slope $=.85, t=13.26, p<.01)($ Fig. 3$)$. 
Table 4 Results of competing models' direct effect of X on Y, indirect effect(s) of X on Y and conditional indirect effects of X on Y

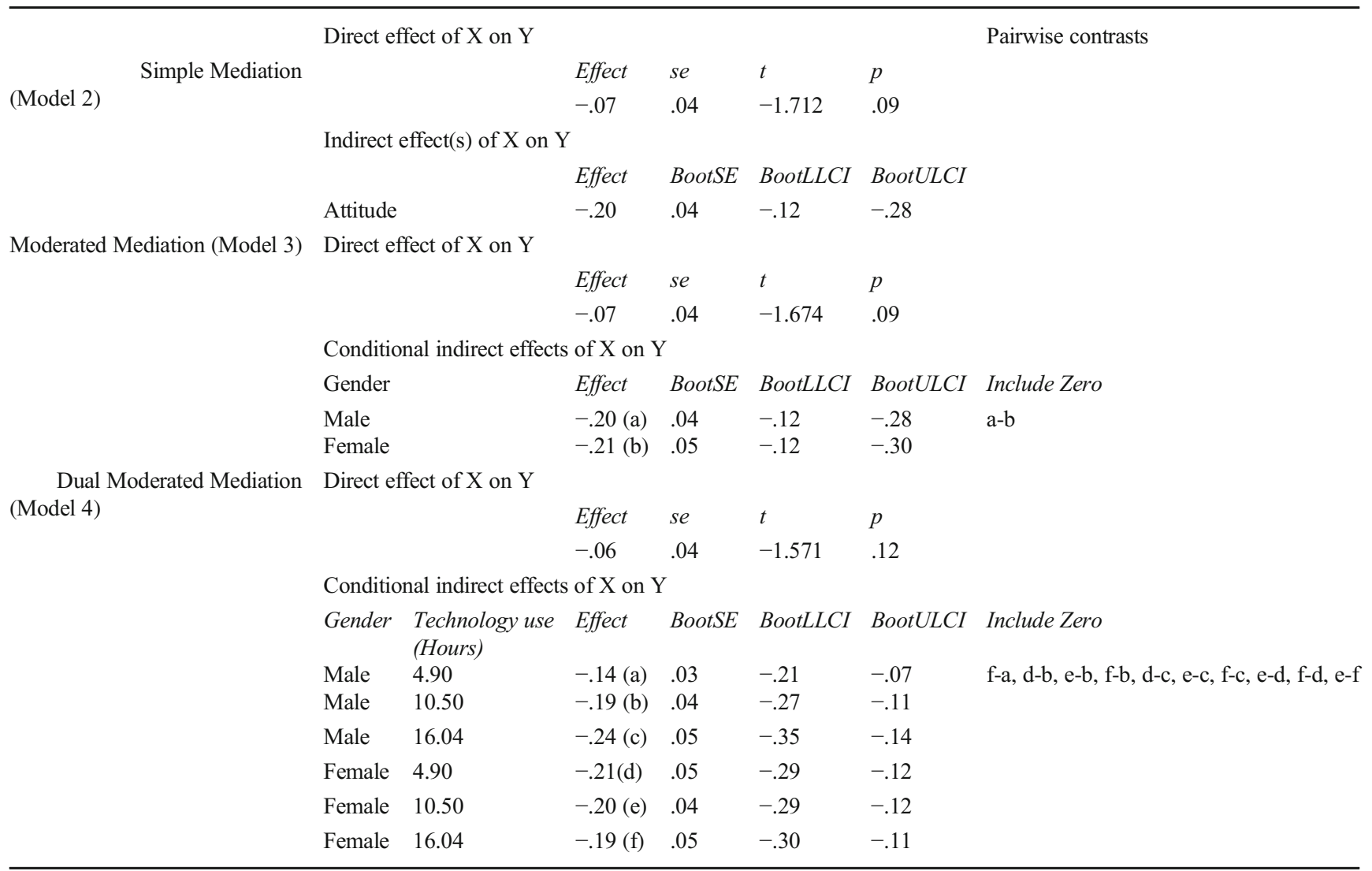

$p^{*}<.05, p^{* *}<.01 ;$ BootSE Bootstrap Standart Error, BootLLCI Bootstrap Lower Limit of Confidence Interval, BootULCI Bootstrap Upper Limit of Confidence Interval; Bootstrap Sample Size $=10^{4}$

\section{Discussion}

To combat the COVID-19 pandemic, many governments have implemented unprecedented measures, like social distancing, social isolation, curfews, and even governmentenforced, large-scale quarantines. This has resulted in technological tools becoming an even more essential source of information, communication, and socialization (Ajzen, 2005; Shankar et al., 2020; Wiederhold, 2020). With the increased use of technology under these circumstances, it is expected that technology dependency will increase, resulting in new problems and conditions for families and teachers.

The results of the present study reveal that adolescents had a moderate level of awareness $(2.07 \pm .37)$, positive attitudes $(3.53 \pm .38)$, and a high level of addictive behavior (3.57 \pm .39 ) in TA during the COVID-19 period. At times of social isolation and prolonged stay-at-home and curfew measures, adolescents use technology for many hours, making it a highly addictive behavior. Furthermore, the study found a positive attitude to TA for this age group.

The results of the competing models of simple, moderated, and dual-moderated mediation demonstrate a wellconstructed model through the hypotheses. In this regard, the results show that the indirect effect of attitude is stronger than that of awareness on the behavior of adolescents in TA. In other words, awareness of TA alone may not be sufficient to measure actual behavior. Perceiving the consequences of behavior indirectly affects attitude and the intention of behavior and the relationship with awareness. Thus, it has been stated that attitude affects behavioral intent and shapes awareness (Ajzen, 2005; Kollmuss \& Agyeman, 2002; Vallerand, Deshaies, Cuerrier, Pelletier, \& Mongeau, 1992). In this respect, the attitude of adolescents to TA becomes an important factor in measuring addictive behavior (Kim \& Choi, 2005). In social psychology, attitude is known to be stronger than the direct influence of awareness on behavior (Streufert, 1987). During the COVID-19 outbreak, parents and teachers have shown positive attitudes towards adolescents' TA because of curfews and distance education. As a matter of fact, when the TA attitudes of adolescents are set against their perceptions of their parents, the adolescents are found to have a positive attitude regardless of how they perceive their parents. However, in order to reach a firm conclusion, it would be useful to conduct qualitative studies with parents and to investigate their children's views on technology use during the pandemic period. 
Fig. 3 Moderating Effects of Attitude to Technology Addiction, Gender and Internet use (hours) on Behavior to Technology Addiction

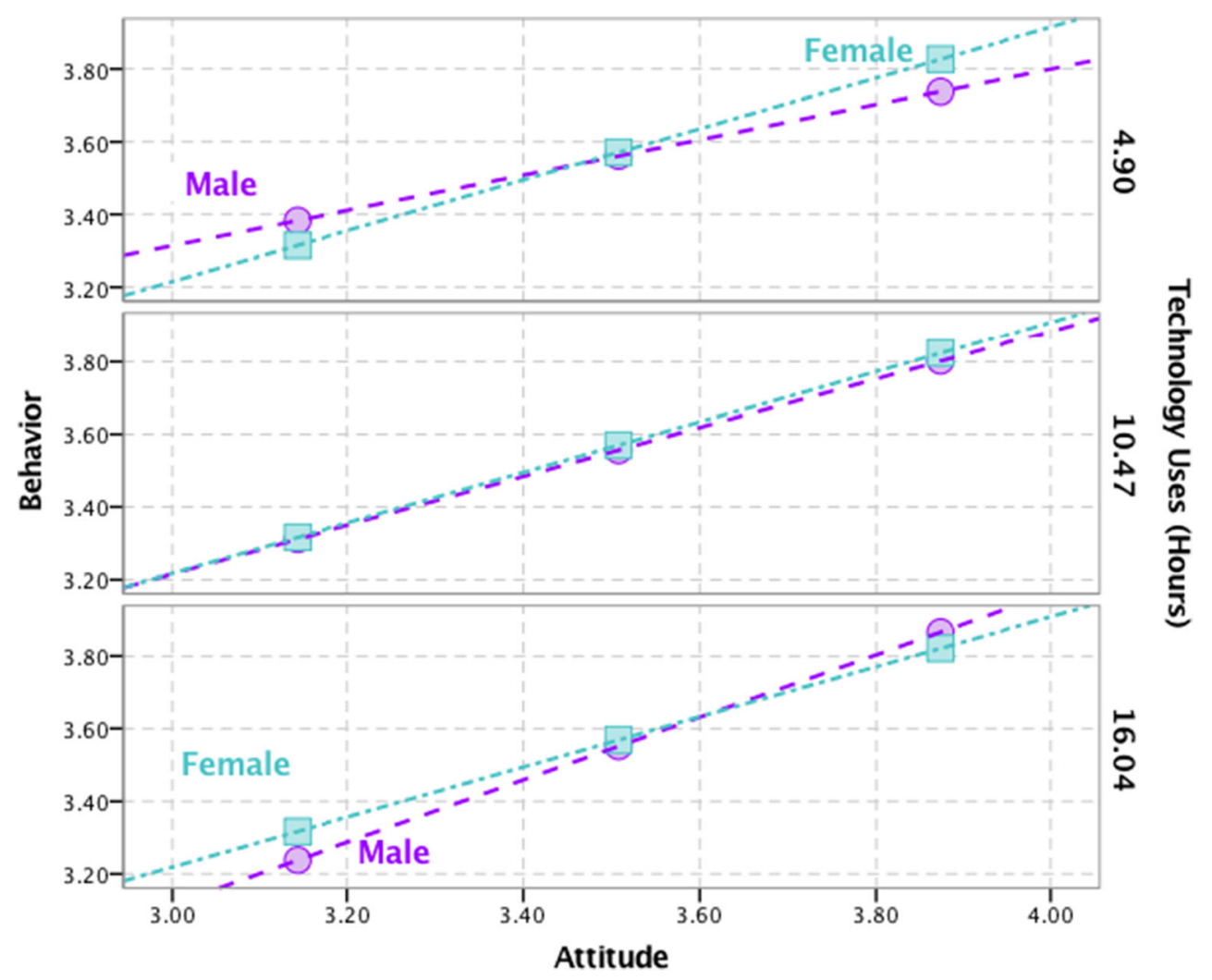

The findings also show that gender does not moderate the indirect effect of attitude on behavior. However, when the extent (duration) of technology use is included, both sex and duration of use moderate the indirect effect of attitude and behavior on TA. Regardless of the duration of technology use, when the attitudes of females were negative, their addictive behavior was lower, and vice versa. In contrast, above $4.90 \mathrm{~h}$ per day of technology use, the attitudes of males turn to negative as addictive behavior increases, and vice versa. This situation can be interpreted in two ways. Firstly, although male adolescents have a negative attitude to TA, they may not have behavioral control for organic reasons such as problems in impulse control or/and behavior problems (Benbir, Poyraz, \& Apaydın, 2014; Hekim et al., 2019). According to the informal social control theory (Mason \& Windle, 2002), behavior problems are more prevalent among boys. Secondly, even though they have a negative attitude, they may normalize technology use due to the lack of social activities under COVID-19 circumstances and consider it a temporary and ordinary form of behavior. Male adolescents and female adolescents with $16.04 \mathrm{~h}$ of extreme use may have no parental monitoring or parents with an excessively permissive attitude. In this study, only $21 \%$ of adolescents defined their parents as authoritative and $36 \%$ defined them as permissive. However, according to the preliminary findings of this study, regardless of how adolescents define their parents, their TA addiction scores are high. Having said that, the parental attitudes were not evaluated with a standardized measurement tool. As a matter of fact, previous studies have shown that adolescents with authoritarian parents are more technology-addictive than adolescents with more democratic parents (Floros \& Siomos, 2013; Moazedian et al., 2014). In addition, Tafà and Baiocco (2009) found that adolescent addictions increase in families characterized by weak emotional bonds and the incapacity to change their role relationships, power structure, and relationship rules in response to situational and developmental stress (high adaptability; Tafà \& Baiocco, 2009). Given that the COVID-19 pandemic is a situational stressor, familial and parental factors may have an influence on some adolescents' TA. Even though these findings support the theoretical explanations, researchers may wish to conduct future studies with a mixed method and broader sample (including parents) in order to arrive at stronger conclusions.

With $16.04 \mathrm{~h}$ per day of technology use, some male adolescents' attitudes to TA become negative and the addictive behavior decreases. It is thought that the adolescents in this group are those who perceive the negative influences of TA, such as sleeplessness etc., have no problems like impulse control, and can control themselves. On the other hand, with $16.04 \mathrm{~h}$ per day of technology use, some male adolescents' attitudes to TA become positive, and the addictive behavior increases. It is thought that the adolescents in this group are individuals who may consider technology use a means of escape from the stress factors in their lives and/or use 
technology to increase their social interaction and integration and meet their need for socialization. What distinguishes the two groups may be the nature of the adolescents' individual needs and the parenting attitudes of their parents. The literature emphasizes the importance of individual needs (e.g., the need for relationships and the need for escapism) in TA development (Xu et al., 2012). These adolescents are highly likely to be addicted to technology, putting them in the atrisk group.

The present study has some limitations. Data was collected through an online survey, and participants could not be assessed face-to-face. However, this limitation was unavoidable due to the social distancing restrictions put in place by the government to combat the COVID-19 outbreak. In addition, the literature indicates that online surveys are a good method when it is impossible to use longer methods (Błachnio, Przepiorka, Senol-Durak, Durak, \& Sherstyuk, 2017). Secondly, since the level of use of technology was not recorded before the confinement and the study is a cross-sectional one, the cause and effect relationship cannot be established and conclusive statements cannot be made. Thirdly, as the sample comprised Turkish adolescents, it is important to generalize the findings through further studies in different cultural settings. In other words, while the findings of the study can be generalized to groups exhibiting similar characteristics to the participants of this study, cross-cultural comparative studies are needed in order to reach a stronger conclusion. Finally, this study used a concept of technology use which was not differentiated by device or connection. Different forms of technology use could be treated separately in future face-to-face studies. Also, the model can be improved and re-tested after the break of the pandemic.

\section{Implications}

Despite the limitations mentioned above, this study makes significant contributions to the existing literature. As known, modeling is a tool for thinking, understanding, recognizing and developing the theory (Braithwaite, 1953; Hutten, 1954; Toon, 2016). In other words, recent studies showed that models are representations of ways of thinking and understanding the world, models are always interpretive not simply developed by the phenomena (Açıalın, 2020; Bailer Jones, 2009). Our model is more than data-oriented but also effects of variables are stated related to TA in the literature has been investigated. It is a new model that would contribute to the existing literature.

The results of the current study suggest that as the physiological and psychological effects of COVID-19 continue, TA is an inevitable problem for adolescents. In response, emphasis may be placed on psychoeducational activities to reduce attitudes to TA. The psychoeducational intervention programs to be implemented should not only focus on awareness, but should also encompass behavioral, cognitive and lifestyle changes. Considering the effects of the pandemic on lifestyles, in-house rules for domestic activities can be established, and parents can act as models for their children by applying these rules themselves. For example, a time period could be set when no one in the household uses technological devices and all family members could participate in joint activities during this period. Prevention strategies might include a return to "oldstyle" games, the development of manual skills, and stimulation of the imagination in other ways, such as by playing games that appeal to all five senses. In addition, parents and teachers should perhaps request additional support and education regarding this issue from both governmental and nongovernmental organizations in order to help combat a TA pandemic. Some work could be carried out through the media. Furthermore, screening studies could be performed for adolescents in order to increase their well-being, and individual and group psychological counselling services could be provided for adolescents with TA and those who have potential for TA.

\section{Appendix 1}

First, a validity and reliability study was conducted. The online survey was sent to the e-mail addresses and smartphones of 180 candidate participants, and 152 participants received the message. The criteria for inclusion and exclusion in the study were the same as for the main analysis. Based on these criteria, 18 online surveys were excluded for reasons of validity and reliability. The study was conducted with the 134 participants who expressed willingness to complete the online survey in full. The aim was to determine whether the 19 items in the "Awareness of TA Scale," the 8 items in the "Attitude to TA Scale," and the 10 items in the "Behavior in TA Scale" were fit for purpose and to determine that meaningful and valid data were collected. Accordingly, exploratory factor analysis (EFA) and confirmatory factor analysis were used to test the construct validity of the scale. In the EFA, the varimax vertical rotation method and principal components analysis were used, while in the confirmatory factor analysis, the maximum likelihood estimation was used. In the EFA, the criteria taken into consideration included the elimination of items that do not measure the same structure, the common factor variance of the items, factor eigenvalues, the total variance ratio explained, item factor loads, the presence or absence of contradictory items, and the representation of the theoretical infrastructure to be measured. Accordingly, the communalities of the items were required to be greater than .10 , the factor eigenvalues greater than 1 , the total variance greater than $50 \%$ (30\% of the total variance explained in single-factor scales), and the item factor loads greater than .40. A difference of at least .10 was observed between the 
overlapping items collected under more than one factor in multidimensional scales. As a result of the EFA, three items of the scale were excluded from use because they overlapped.
None of the remaining items were found to be statistically problematic and they conformed to determined criteria
Fig. 4 The path diagram of the Awareness in Technology Addiction Scale

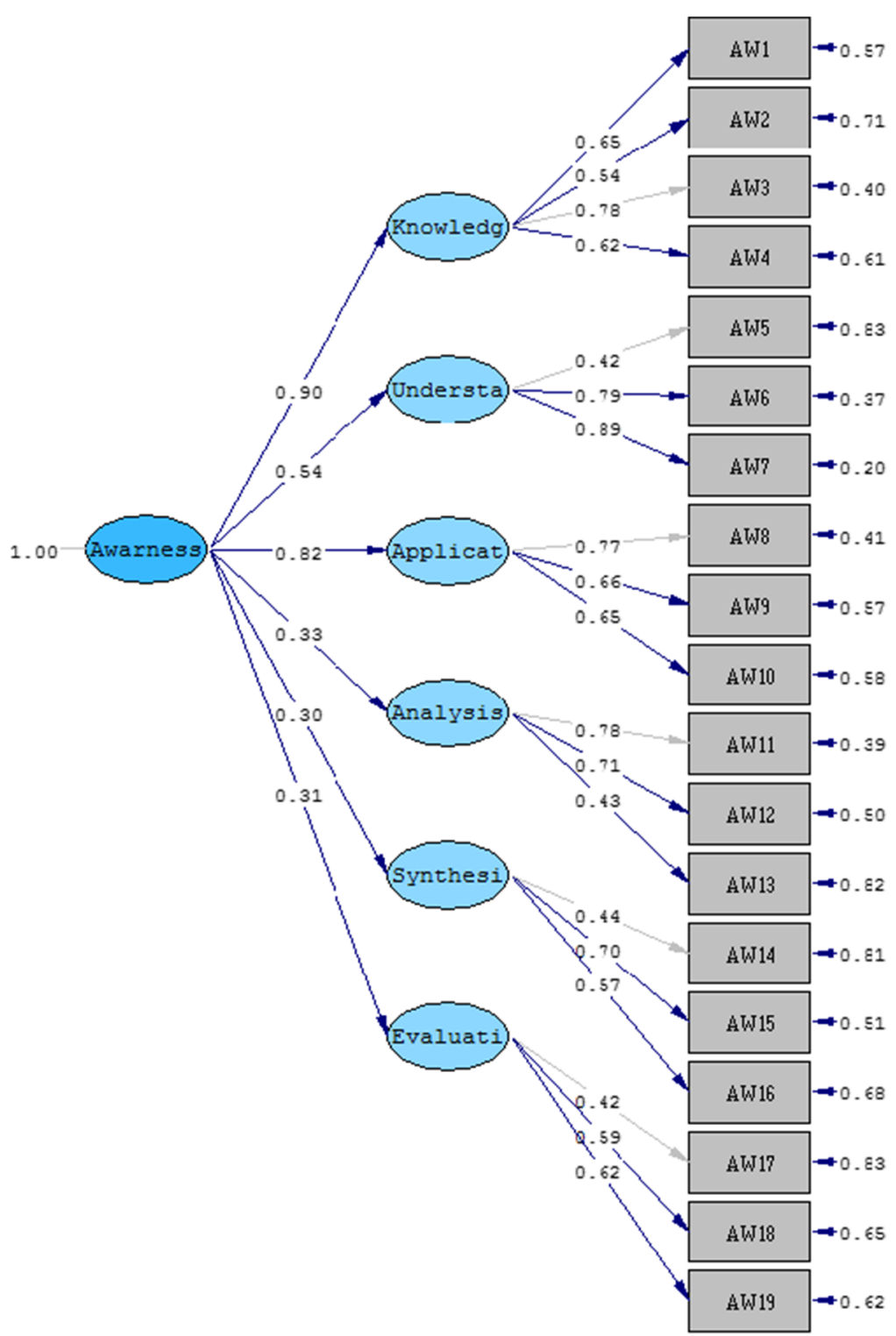

Chi-Square=208.74, df=146, P-value=0.00051, RMSEA=0.039 
Fig. 5 The path diagram of the Attitude in Technology Addiction Scale

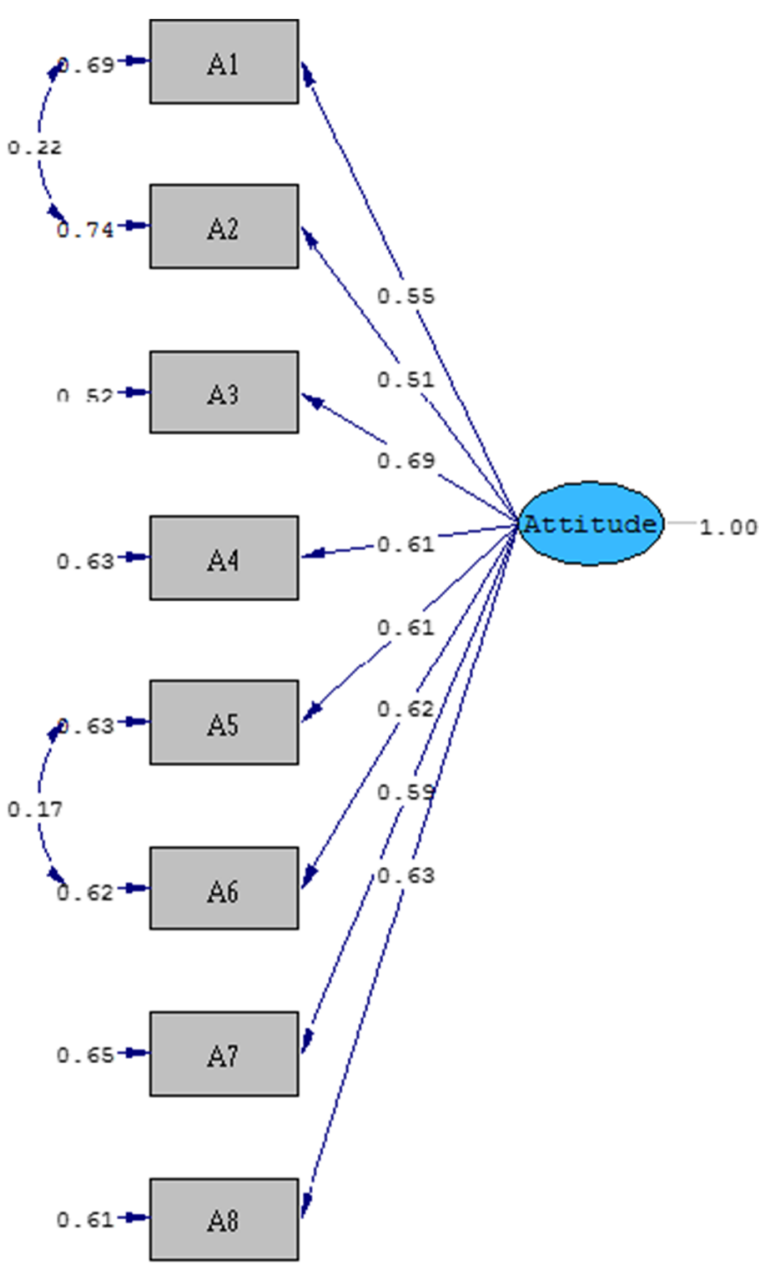

Chi-Square $=45.63, \mathrm{df}=18, \mathrm{P}$-value $=0.00034, \mathrm{RMSEA}=0.078$ 
Fig. 6 The path diagram of the Behavior in Technology Addiction Scale

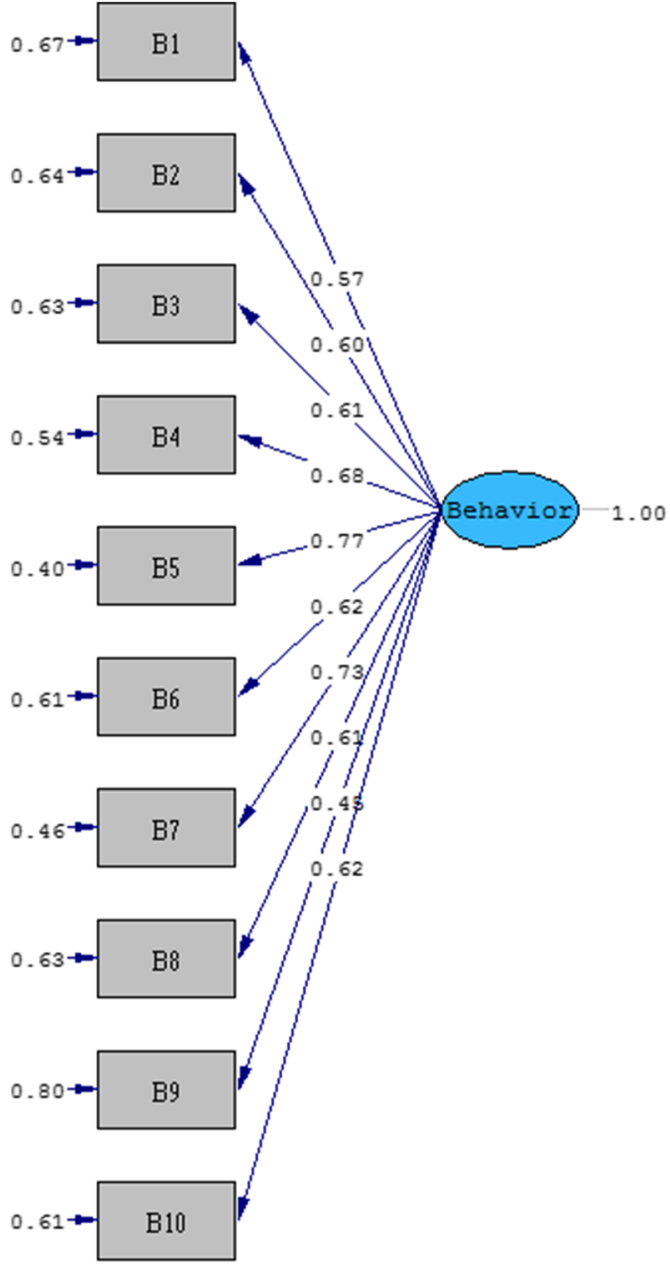

Chi-Square $=89.95, d f=35, P-$ value $=0.00000$, RMSEA $=0.075$
Funding This research did not receive any specific grant from funding agencies in the public, commercial, or not-for-profit sectors.

Data Availability The datasets generated during and/or analyzed during the current study are available from the corresponding author on reasonable request.

\section{Declarations}

Author Agreement All authors have seen and approved the final version of the manuscript being submitted. We warrant that the article is our original work, hasn't received prior publication and isn't under consideration for publication elsewhere.

Declaration of Interest All authors declare that there's no financial/ personal interest or belief that could affect our objectivity.

Conflict of Interest None of the authors had any conflicts of interest.

\section{References}

Açıalın, Ș. N. (2020). Foreign policy and political leadership: Recep Tayyip Erdoğan and Angela Merkel (PhD's thesis, Middle East Technical University).

Adiele, I., \& Olatokun, W. (2014). Prevalence and determinants of internet addiction among adolescents. Computers in Human Behavior, 31(1), 100-110. https://doi.org/10.1016/j.chb.2013.10.028.

Ahorsu, D. K., Lin, C. Y., Imani, V., Saffari, M., Griffiths, M. D., \& Pakpour, A. H. (2020). The fear of COVID-19 scale: Development and initial validation. International journal of mental health and addiction, 1-9. https://doi.org/10.1007/s11469-020-00270-8.

Ajzen, I. (2005). Atitudes, Personality and Behavior. London: Open University Press.

Ajzen, I. (2012). Martin Fishbein's legacy: The reasoned action approach. The Annals of the American Academy of Political and Social Science, 640(1), 11-27. 
Aliyev, J. (2020). Digital detox important in COVID-19 era: Expert. Retrieved from: https://www.aa.com.tr/en/health/digital-detoximportant-in-covid-19-era-expert/1804327. Accessed 18 Oct 2020.

American Psychiatric Association. (2013). Diagnostic and statistical manual of mental disorders (DSM-5®). Washington: APA.

Ardies, J., De Maeyer, S., Gijbels, D., \& van Keulen, H. (2015). Students attitudes towards technology. International Journal of Technology and Design Education, 25(1), 43-65. https://doi.org/10.1007/ s10798-014-9268-x.

Ayas, T., \& Horzum, M. (2013). Relation between depression, loneliness, self-esteem and internet addiction. Education, 133(3), 283-290.

Bailer Jones, D. M. (2009). Scientific models in philosophy of science. Pittsburgh: University of Pittsburgh Press.

Bandawar, M., Narasimha, V. L., \& Chand, P. (2018). Use of digital technology in addiction disorders. Indian Journal of Psychiatry, 60(Suppl 4), S534-S540. https://doi.org/10.4103/psychiatry. IndianJPsychiatry_21_18.

Bandura, A. (1969). Social-learning theory of Identificatory processes. Handbook of Socialization Theory and Research., 26, 471-481. https://doi.org/10.1080/19371918.2011.591629.

Benbir, G., Poyraz, C. A., \& Apaydın, H. (2014). Diagnostic approach to behavioral or "NonSubstance" addictions. Nobel Medicus, 10(1), 511.

Błachnio, A., Przepiorka, A., Senol-Durak, E., Durak, M., \& Sherstyuk, L. (2017). The role of personality traits in Facebook and internet addictions: A study on polish, Turkish, and Ukrainian samples. Computers in Human Behavior, 68, 269-275. https://doi.org/10. 1016/j.chb.2016.11.037.

Braithwaite, R. B. (1953). Scientific explanation; a study of the function of theory, probability and law in science. Cambridge: Cambridge University Press.

Cai, Z., Fan, X., \& Du, J. (2017). Gender and attitudes toward technology use: A meta-analysis. Computers \& Education, 105, 1-13. https:// doi.org/10.1016/j.compedu.2016.11.003.

Chen, S. H., Weng, L. J., Su, Y. J., Wu, H. M., \& Yang, P. F. (2003). Development of Chinese internet addiction scale and its psychometric study. Chinese Journal of Psychology, 45(3), 279-294.

Cheung, L. M., \& Wong, W. S. (2011). The effects of insomnia and internet addiction on depression in Hong Kong Chinese adolescents: An exploratory cross-sectional analysis. Journal of Sleep Research, 20(2), 311-317. https://doi.org/10.1111/j.1365-2869.2010.00883.x.

Cho, S. M., Sung, M. J., Shin, K. M., Lim, K. Y., \& Shin, Y. M. (2013). Does psychopathology in childhood predict internet addiction in male adolescents? Child Psychiatry \& Human Development, 44(4), 549-555. https://doi.org/10.1007/s10578-012-0348-4.

Coolican, H. (2017). Research methods and statistics in psychology. New York: Routledge. https://doi.org/10.4324/9780203769836.

Davis, R. A. (2001). A cognitive-behavioral model of pathological internet use. Computers in Human Behavior, 17, 187-195. https://doi. org/10.1016/S0747-5632(00)00041-8.

Dinçman, M.P. \& Akbaşl1, S. (2020). Araștırma Süreci. In Ș. Ș. Erçetin. (Ed.), Araştırma Teknikleri (pp. 49-62). Ankara: Nobel Yayıncılık.

Dufour, M., Brunelle, N., Tremblay, J., Leclerc, D., Cousineau, M. M., Khazaal, Y., Légaré, A. A., Rousseau, M., \& Berbiche, D. (2016). Gender difference in internet use and internet problems among Quebec high school students. Canadian Journal of Psychiatry, 61(10), 663-668. https://doi.org/10.1177/0706743716640755.

Düzgün, Ș. (2003). Öğrencilerin psikolojik belirtileri ile ana-baba tutumları arasındaki ilişkiler. Atatürk Üniversitesi Sosyal Bilimler Enstitüsü Dergisi.

Ebbeck, M., Yim, H. Y. B., Chan, Y., \& Goh, M. (2016). Singaporean parents' views of their young children's access and use of technological devices. Early Childhood Education Journal, 44(2), 127134. https://doi.org/10.1007/s10643-015-0695-4.

El Zowalaty, M. E., \& Järhult, J. D. (2020). From SARS to COVID-19: A previously unknown SARS- related coronavirus (SARS-CoV-2) of pandemic potential infecting humans - Call for a one health approach. One Health, 9, 100124. https://doi.org/10.1016/j.onehlt. 2020.100124.

Eliacik, K., Bolat, N., Koçyiğit, C., Kanik, A., Selkie, E., Yilmaz, H., Catli, G., Dundar, N. O., \& Dundar, B. N. (2016). Internet addiction, sleep and health-related life quality among obese individuals: A comparison study of the growing problems in adolescent health. Eating and Weight Disorders: EWD, 21(4), 709-717. https://doi. org/10.1007/s40519-016-0327-z.

Fishbein, M., \& Ajzen, I. (2010). Predicting and changing behavior: The reasoned action approach. New York: Psychology Press.

Floros, G., \& Siomos, K. (2013). The relationship between optimal parenting, internet addiction and motives for social networking in adolescence. Psychiatry Research, 209(3), 529-534. https://doi.org/10. 1016/j.psychres.2013.01.010.

Gerçel, E., \& Çağlar, M. (2016). Impact assessment of technology use towards the aggression and anger in adolescents. The Online Journal of New Horizons in Education, 6(3), 81-87. https://www. tojned.net/journals/tojned/articles/v06i03/v06i03-06.pdf.

Gough, H. G., \& Heilbrun, A. B. (1965). The Adjective Check List manual. Palo Alto, CA: Consulting Psychologists Press.

Ha, Y. M., \& Hwang, W. J. (2014). Gender differences in internet addiction associated with psychological health indicators among adolescents using a national web-based survey. International Journal of Mental Health and Addiction, 12(5), 660-669. https://doi.org/10. 1007/s11469-014-9500-7.

Hair, J. F., Gabriel, L. D. S., da Silva, M. D., \& Braga Junior, S. (2019). Development and validation of attitudes measurement scales: Fundamental and practical aspects. RAUSP Management Journal, 54(4), 490-507. https://doi.org/10.1108/RAUSP-05-2019-0098.

Hayes, A. F. (2013). Methodology in the social sciences. In Introduction to mediation, moderation, and conditional process analysis: A regression-based approach. New York: Guilford Press.

Hayes, A. F. (2015). An index and test of linear moderated mediation. Multivariate Behavioral Research, 50(1), 1-22. https://doi.org/10. 1080/00273171.2014.962683.

Hekim, Ö., Göker, Z., Aydemir, H., Çöp, E., Dinç, G., \& Üneri, Ö. (2019). Ergenlerde internet bağımlılığı ve psikopatoloji ile ilişkisi: Kesitsel bir çalıșma [internet addiction and its relation with psychopathology in adolescents: A cross-sectional study]. Klinik Psikiyatri Dergisi, 22(3), 329-337. https://doi.org/10.5505/kpd.2019.80488.

Hinić, D., Mihajlović, G., Špirić, Ž., Dukić-Dejanović, S., \& Jovanović, M. (2008). Excessive internet use: Addiction disorder or not? Vojnosanitetski Pregled, 65(10), 763-767. https://doi.org/10.2298/ VSP0810763H.

Hutten, E. H. (1954). The role of models in physics. The British Journal for the Philosophy of Science, 4(16), 284-301.

Jabbar, S. A., Al-Shboul, M., Tannous, A., Banat, S., \& Aldreabi, H. (2019). Young children's use of technological devices: Parents' views. Modern Applied Science, 13(2), 66-80. https://doi.org/10. 5539/mas.v13n2p66.

Kağıtçıbaşı, Ç. (2010). Self, family and human development: Cultural psychology. İstanbul: Koç University Press.

Karadağ, E., \& Kılıç, B. (2019). Öğretmen görüşlerine göre öğrencilerdeki teknoloji bağımlılığ [Technology addiction among students according to teacher views]. Current Approaches in Psychiatry, 11(1), 101-117. https://doi.org/10.18863/pgy.556689.

Karapetsas, A. V., \& Fotis, A. I. (2020). Neuropsychology as a method of diagnosis and treatment of internet addiction. Addictive Disorders and Their Treatment, 19(1), 56-65. https://doi.org/10.1097/ADT. 0000000000000182.

Kim, Y., \& Choi, S. M. (2005). Antecedents of green purchase behaviour: An examination of collectivism, environmental concern, and PCEE. Advances in Consumer Research, 32, 592-599. https://doi.org/10. 1177/004057368303900411. 
King, D. L., Delfabbro, P. H., Billieux, J., \& Potenza, M. N. (2020). Problematic online gaming and the COVID-19 pandemic. Journal of Behavioral Addictions, 9(2), 184-186. https://doi.org/10.1556/ 2006.2020.00016.

Király, O., Potenza, M. N., Stein, D. J., King, D. L., Hodgins, D. C., Saunders, J. B., Griffiths, M. D., Gjoneska, B., Billieux, J., Brand, M., Abbott, M. W., Chamberlain, S. R., Corazza, O., Burkauskas, J., Sales, C. M. D., Montag, C., Lochner, C., Grünblatt, E., Wegmann, E., Martinotti, G., Lee, H. K., Rumpf, H. J., Castro-Calvo, J., Rahimi-Movaghar, A., Higuchi, S., Menchon, J. M., Zohar, J., Pellegrini, L., Walitza, S., Fineberg, N. A., \& Demetrovics, Z. (2020). Preventing problematic internet use during the COVID-19 pandemic: Consensus guidance. Comprehensive Psychiatry, 100, 152180. https://doi.org/10.1016/j.comppsych.2020.152180.

Kollmuss, A., \& Agyeman, J. (2002). Mind the gap: Why do people act environmentally and what are the barriers to pro-environmental behavior? Environmental Education Research, 8(3), 239-260. https:// doi.org/10.1080/13504620220145401.

Kuss, D. J., Griffiths, M., Karila, L., \& Billieux, J. (2014). Internet addiction: A systematic review of epidemiological research for the last decade. Current Pharmaceutical Design, 20(25), 4026-4052. https://doi.org/10.2174/13816128113199990617.

Kuss, D. J., \& Griffiths, M. D. (2015). Internet addiction in psychotherapy. Palgrave Macmillan UK. https://doi.org/10.1057/ 9781137465078.

Kuss, D. J., Van Rooij, A. J., Shorter, G. W., Griffiths, M. D., \& Van De Mheen, D. (2013). Internet addiction in adolescents: Prevalence and risk factors. Computers in Human Behavior, 29(5), 1987-1996. https://doi.org/10.1016/j.chb.2013.04.002.

Kwon, M., Lee, J. Y., Won, W. Y., Park, J. W., Min, J. A., Hahn, C., Gu, X., Choi, J. H., \& Kim, D. J. (2013). Development and validation of a smartphone addiction scale (SAS). PLoS One, 8(2), e56936. https://doi.org/10.1371/journal.pone.0056936.

Louangrath, P. (2018). Reliability and validity of survey scales. International Journal of Research \& Methodology in Social Science, 4(1), 50-62. https://doi.org/10.5281/zenodo.1322695.

Magsamen-Conrad, K., Billotte-Verhoff, C., \& Greene, K. (2014). Technology addiction's contribution to mental wellbeing: The positive effect of online social capital. Computers in Human Behavior, 40, 23-30. https://doi.org/10.1016/j.chb.2014.07.014.

Mason, W. A., \& Windle, M. (2002). Gender, self-control, and informal social control in adolescence: A test of three models of the continuity of delinquent behavior. Youth and Society, 33(4), 479-514. https:// doi.org/10.1177/0044118x02033004001.

Mcleod, S. (2009). Attitude Measurement simplypsychology.org/attitudemeasurement.html. Simply psychology. Retrieved from: https:// www.simplypsychology.org/attitude-measurement.html. Accessed 18 Oct 2020.

Moazedian, A., Taqavi, S. A., Hosseinialmadani, S. A., Mohammadyfar, M. A., \& Sabetimani, M. (2014). Parenting style and internet addiction. J. Life Sci. Biomed. Journal Homepage: J. Life Sci. Biomed, 4(41), 9-14 http://jlsb.science-line.com/.

Montaño, D. E., \& Kasprzyk, D. (2015). The theory of reasoned action and the theory of planned behavior. In K. Glanz, B. K. Rimer, \& F. M. Lewis (Eds.), Health behavior and health education: Theory, research, and practice (pp. 67-99). San Francisco: Jossey-Bass.

Okunlola, M. A., Lamptey, E., Senkyire, E. K., Dorcas, S., \& Dooshima, B. A. (2020). Perceived myths and misconceptions about the novel COVID-19 outbreak. SciMedicine Journal, 2(3), 108-117.

Osatuyi, B., \& Turel, O. (2019). Social motivation for the use of social technologies. Internet Research, 29, 24-45.

Portney, L. G., \& Watkins, M. P. (2007). Foundations of clinical research: Applications to practice (3th ed.). Upper Saddle River: Prentice Hall.

Potas, N., Erçetin, Ș. Ș., Nilhan Açıkalın, Ș., Güngör, H., \& Soydaș Akyol, E. (2018). A comprehensive study on addiction: 3D scale on youth. Addicta: The Turkish Journal on Addictions, 5(3), 559575. https://doi.org/10.15805/addicta.2018.5.3.0022.

Potas, N., Erçetin, S. S., Yilmaz, M., Açikalin, S. N., Güngör, H., \& Akyol, E. S. (2016). 3D scale for awareness, attitude, stigma of addiction. Studies on Ethno-Medicine, 10(2), 156-165. https://doi. org/10.1080/09735070.2016.11905484.

Prensky, M. (2001). Digital natives, digital immigrants part 1. On the Horizon, 9, 1-6. https://doi.org/10.1108/10748120110424816.

Sáinz, M., \& López-Sáez, M. (2010). Gender differences in computer attitudes and the choice of technology-related occupations in a sample of secondary students in Spain. Computers \& Education, 54(2), 578-587. https://doi.org/10.1016/j.compedu.2009.09.007.

Selai, C. (1998). Cambridge handbook of psychology, health and medicine. Journal of the Royal Society of Medicine, 91(5), 288.

Serenko, A., \& Turel, O. (2020). Directing technology addiction research in information systems: Part I. Understanding behavioral addictions. ACM SIGMIS Database: the DATA BASE for Advances in Information Systems, 51(3), 81-96. https://doi.org/10.1145/ 3410977.3410982 .

Shankar, M., Fischer, M., Brown-Johnson, C. G., Safaeinili, N., Haverfield, M. C., Shaw, J. G., Verghese, A. \& Zulman, D. M. (2020). Humanism in telemedicine: Connecting through virtual visits during the COVID-19 pandemic. COVID-19: Annals of Family Medicine. Retrieved from: http://hdl.handle.net/2027.42/ 154738

Shashaani, L. (1994). Socioeconomic status, parents' sex role stereotypes, and the gender gap in computing. Journal of Research on Computing in Education, 26(4), 433-451.

Shelton, L. G. (2018). The Bronfenbrenner primer: A guide to develecology (1st ed.). London: Routledge.

Streufert, S. (1987). Applied social psychology. Journal of Applied Social Psychology, 17, 605-608. https://doi.org/10.1111/j.15591816.1987.tb01172.x.

Su, W., Han, X., Jin, C., Yan, Y., \& Potenza, M. N. (2019). Are males more likely to be addicted to the internet than females? A metaanalysis involving 34 global jurisdictions. Computers in Human Behavior, 99, 86-100. https://doi.org/10.1016/j.chb.2019.04.021.

Sweldens, S., Corneille, O., \& Yzerbyt, V. (2014). The role of awareness in attitude formation through evaluative conditioning. Personality and Social Psychology Review, 18(2), 187-209. https://doi.org/10. $1177 / 1088868314527832$.

Tafà, M., \& Baiocco, R. (2009). Addictive behavior and family functioning during adolescence. American Journal of Family Therapy, 37(5), 388-395. https://doi.org/10.1080/01926180902754745.

Tao, Z. (2013). The relationship between internet addiction and bulimia in a sample of Chinese college students: Depression as partial mediator between internet addiction and bulimia. Eating and Weight Disorders: EWD, 18(3), 233-243. https://doi.org/10.1007/s40519013-0025-z.

Toon, A. (2016). Imanigation in scientific modeling. In A. Kind (Ed.), The Routledge handbook of philosophy of imagination (pp. 451463). Routledge.

TÜİK. (2013). 06-15 yaş grubu çocuklarda bilişim teknolojileri kullanımı ve medya, 2013. Retrieved from: http://www.tuik.gov.tr/ PreHaberBultenleri.do?id=15866. Accessed 18 Oct 2020.

TÜİK. (2019a). Hanehalkı bilişim teknolojileri (BT) kullanım araştırmasl, 2019. Retrieved from: http://www.tuik.gov.tr/ PreHaberBultenleri.do?id=30574. Accessed 18 Oct 2020.

TÜİK. (2019b). Türkiye nüfusu yaş gruplarına göre dağılımı 2019. Retrieved from: https://biruni.tuik.gov.tr/medas $/ \mathrm{kn}=95 \&$ locale $=$ tr. Accessed 18 Oct 2020.

Turel, O., Serenko, A., \& Giles, P. (2011). Integrating technology addiction and use: An empirical investigation of online auction users. MIS Quarterly, 35(4), 1043-1061.

UN Women (2020). COVID-19 and ending violence against women and girls. Retrieved from: https://www.unwomen.org/en/digital-library/ 
publications/2020/04/series-evaw-covid-19-briefs. Accessed 18 Oct 2020.

Vallerand, R. J., Deshaies, P., Cuerrier, J. P., Pelletier, L. G., \& Mongeau, C. (1992). Ajzen and Fishbein's theory of reasoned action as applied to moral behavior: A confirmatory analysis. Journal of Personality and Social Psychology, 62(1), 98-109. https://doi.org/10.1037/ 0022-3514.62.1.98.

VandenBos, G. R. (2015). APA dictionary of psychology. Washington, DC: American Psychological Association.

Vollmer, C., Randler, C., Horzum, M. B., \& Ayas, T. (2014). Computer game addiction in adolescents and its relationship to chronotype and personality. SAGE Open, 4(1), 1-9. https://doi.org/10.1177/ 2158244013518054.

Wang, C., Horby, P. W., Hayden, F. G., \& Gao, G. F. (2020). A novel coronavirus outbreak of global health concern. The Lancet, 395(10223), 470-473. https://doi.org/10.1016/S0140-6736(20) 30185-9.

Widyanto, L., Griffiths, M. D., \& Brunsden, V. (2011). A psychometric comparison of the internet addiction test, the internet-related problem scale, and self-diagnosis. Cyberpsychology, Behavior and Social Networking, 14(3), 141-149.

Wiederhold, B. K. (2020). Social media use during social distancing. Cyberpsychology, Behavior and Social Networking, 23(5), 275276. https://doi.org/10.1089/cyber.2020.29181.bkw.

Winther, D. K., \& Byrne, J. (2020). Rethinking screen-time in the time of COVID-19. UNICEF for every child. Retrieved from: https://www. unicef.org/globalinsight/stories/rethinking-screen-time-time-covid19. Accessed 18 Oct 2020

World Health Organization (2020). Addressing violence against children, women and older people during the covid-19 pandemic: Key actions. Retrieved from: https://www.who.int/publications/i/item/ WHO-2019-nCoV-Violence actions-2020.1. Accessed 18 Oct 2020.

Xie, X., Chen, W., Zhu, X., \& He, D. (2019). Parents' phubbing increases adolescents' mobile phone addiction: Roles of parent-child attachment, deviant peers, and gender. Children and Youth Services Review, 105, 104426. https://doi.org/10.1016/j.childyouth.2019. 104426.

Xu, Z., Turel, O., \& Yuan, Y. (2012). Online game addiction among adolescents: Motivation and prevention factors. European Journal of Information Systems, 21, 321-340. https://doi.org/10.1057/ejis. 2011.56.

Yau, H. K., \& Cheng, A. L. F. (2012). Gender difference of confidence in using technology for learning. Journal of Technology Studies, 38(2), 74-79.

Ybarra, M. L., \& Mitchell, K. J. (2004). Youth engaging in online harassment: Associations with caregiver-child relationships, internet use, and personal characteristics. Journal of Adolescence, 27(3), 319-336. https://doi.org/10.1016/j.adolescence.2004.03.007.

Young, K. S. (1998). Internet addiction: The emergence of a new clinical disorder. CyberPsychology and Behavior, 1(3), 237-244. https:// doi.org/10.1089/cpb.1998.1.237.

Young, K. S., \& Nabuco de Abreu, C. (2011). Internet addiction: A handbook and guide to evaluation and treatment. Hoboken: Wiley.

Publisher's Note Springer Nature remains neutral with regard to jurisdictional claims in published maps and institutional affiliations. 